\title{
Drohobycz, Drohobycz
}

Drohobych, Drohobych

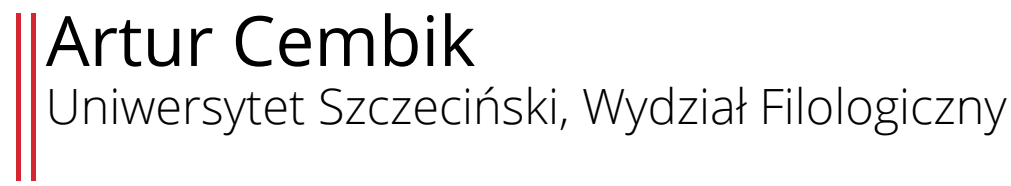

\begin{abstract}
This article focuses on the pre-war image of Drohobycz in Atlantyda and Ziemia księżycowa by Andrzej Chciuk. On account of multicultural borderland town, the concept of work is an attempt to answer the question: how the ethnic, religious and cultural elements function in the dilogy. The mechanism of creating the distinctiveness between Polish, Jewish and Ukrainian community is the crucial issue in the dilogy. This mechanism forms the coherent whole in the memorial prose by Andrzej Chciuk. The article analyzes the convention of tale and specific language "bałak" - the dialect of Lvov and the surrounding area. "Place memorial" is the category that establishes the shape and the quality of stored in recollection world. This provides a foundation of Andrzej Chciuk's memories, which the author describes as "fotoplastikon" or "tapestry". The work also cities the opinions of writers and journalists about Drohobych, who visited this city before the Second World War and in the 21st century. Therefore, the aim of the article is to show different points of view about this border location.
\end{abstract}

Key words: Drohobych, borderland, Borderlands, multinationality (multiethnicism), memory, balaka (Lviv jargon).

Streszczenie: Artykuł skupia się na wizerunku przedwojennego Drohobycza w utworach Atlantyda i Ziemia księżycowa Andrzeja Chciuka. Ze względu na wielokulturowość pogranicznego miasta praca jest próbą odpowiedzi na pytanie, jak w tej dylogii funkcjonują elementy etniczne, religijne i kulturowe. Ważny jest w niej mechanizmu budowania odrębności między polską, żydowską i ukraińską społecznością, które w prozie wspomnieniowej Andrzeja Chciuka tworzą jednolitą całość. W artykule analizuje się też konwencję gawędy, czy specyficznego języka „bałaku” - gwary Lwowa i jego okolic. Kategorią organizującą kształt i jakość przechowywanego we wspomnieniach świata jest „pamięć miejsca". To ona stanowi fundament wspomnień Andrzeja Chciuka, które autor w omawianych utworach określa mianem „fotoplastikonu” lub „arrasu”. W pracy przytacza się także opinie o Drohobyczu pisarzy i publicystów, którzy odwiedzili to miasto przed drugą wojną światową i w XXI wieku. Dlatego celem artykułu jest ukazanie różnych punktów widzenia na temat tego pogranicznego miejsca.

Słowa kluczowe: Drohobycz, pogranicze, Kresy, wielonarodowość (wieloetniczność), pamięć, bałak (lwowski żargon) 
Skojarzenie ze zbiorem opowiadań Henryka Grynberga jest oczywiste - taki też był mój zamiar. Jednak przedmiotem rozważań nie będzie Holokaust i życie ludzi po Zagładzie, lecz próba ujęcia literackich wizerunków przedwojennego miasta, którego cechą charakterystyczną była wieloetniczność. Na czym polega wyjątkowość Drohobycza położonego „w województwie lwowskim, na Pogórzu Karpackim, nad rzeką Tyśmienicą, między Samborem a Stryjem, w bezpośredniej bliskości Borysławia i Truskawca" (Bolecki... 2003, 91)? Odpowiedzi na to pytanie w dalszej części pracy poszukam we wspomnieniowej dylogii Andrzeja Chciuka: Atlantydzie i Ziemi księżycowej.

Kiedy Alfred Döblin, urodzony w Szczecinie Niemiec żydowskiego pochodzenia, za namową przedstawicieli ruchu syjonistycznego w 1924 roku odbył podróż po Polsce, tak pisał o Drohobyczu:

Czworoboczny przestronny plac targowy. Budy i stoły, konie, zaprzęgi, rzędy dorożek. A wszystko tonie w błocie i śmieciach, w słomie, gruzie, odpadkach. Cała linia stołów prezentuje w tym gnoju bele kolorowego sukna (...). Żydzi, sami Żydzi, o niemieckich nazwiskach (...). Strasznie wygląda pośrodku tego placu czworokątna wysoka wieża z zegarem. Wieża stoi samotnie, nie ma przy niej żadnego kościoła, żadnego domu. To noga, od której oderwano tułów (...). A poniżej rynku, ze śmieciami i okropną wieżą, zaczynają się uliczki. Robi się strasznie. Kto nie widział tych ulic i „domów”, ten nie wie, czym jest bieda. To nie domy, to resztki domów, budy, szopy, szałasy. Okna założone deskami, okna bez szyb. Domy bez zamkniętego dachu - rozpadające się baraki, ciasno stłoczone jeden przy drugim; niektóre mają piwnice, wprawdzie murowane, ale podobne do jaskiń. Każda rudera przeludniona (Döblin 2000, 203-204).

Niespełna dziewięćdziesiąt lat po wyprawie Döblina włoski filozof, krytyk i pisarz, Francesco M. Cataluccio, w osobliwym „brewiarzu środkowoeuropejskim" pod tytułem Jadę zobaczyć, czy tam jest lepiej dzieli się wrażeniami z podróży po Europie Środkowo-Wschodniej. Wprawdzie jego opis pozbawiony jest naturalistycznych akcentów występujących u poprzednika, jednak w tym przypadku podróżnika uderza egzotyka przestrzeni, odmienność pejzażu. Kiedy przekracza polsko-ukraińską granicę, fascynuje go nadmiar dzikiej natury, która prowadzi pisarza aż do Drohobycza:

Tak samo dzieje się przy wjeździe do leżącego u podnóża Karpat Drohobycza, gdzie mieszkał Bruno Schulz: a w samym mieście dziesiątki alei, parków i ogrodów zmieniają je w zieloną oazę. Stare wille, ale nawet budynki współczesne, te szare bloki z okresu sowieckiego, ledwo znajdują dla siebie miejsce w tym oceanie liści, kwiatów i bujnej roślinności (Cataluccio 2012, 300).

O imaginacyjnej podróży po Galicji Wschodniej i Bukowinie, a jednocześnie próbie wskrzeszenia świata, którego już nie ma, pisał Martin Pollack, austriacki eseista i publicysta. Autor Topografii pamięci dostrzegł w Drohobyczu „galicyjską Pensylwanię” dzięki odkrytym w okolicy złożom ropy naftowej, która błyskawicznie zmieniła życie prowincjonalnego miasta. Na początku XX wieku przy schulzowskiej „ulicy Krokodyli” zaczęły powstawać rezydencje królów naftowych i przemysłowców, zaś chodnikami 
miasta przemykali umorusani tragarze nafty. I właśnie ów przekrój społeczny przedwojennego Drohobycza zajmuje Pollacka najbardziej. Bezsprzecznie najsilniejszą grupę narodowościową stanowili tu Żydzi, w większości posługujący się językiem niemieckim. Drugą byli Rusini, a dopiero trzecią - pozostający w mniejszości Polacy. Dane statystyczne potwierdzają spostrzeżenia Döblina. Autor Podróży po Polsce z przejęciem daje świadectwo spotkań z drohobycką biedotą:

Szlaban, droga zakręca, i oto - prosta jak strzelił, wąska ulica, po której grzęzawisku kręcą się w obu kierunkach bryczki. Jadą szybko: z lewa i prawa ludzie chodzą po deskach ułożonych wysoko na drewnianych balach. Pod spodem płyną nieczystości, błoto. Grzęzawisko spływa z wyżej położonych przecznic. Na tej wodzie dawniej była warstwa ropy; zbierali ją biedacy. Zgraje ludzi w centrum miejscowości, natężony ruch wozów (Döblin 2000, 206-207).

Drohobycz jest rodzinnym miastem nie tylko Brunona Schulza czy Kazimierza Wierzyńskiego, tu bowiem w 1920 roku przyszedł na świat Andrzej Chciuk, który - będąc na emigracji - porównał je do bezpowrotnie utraconej Atlantydy. Tu ukończył Gimnazjum im. Króla Władysława Jagiełły, a jednym z jego nauczycieli był właśnie autor Sklepów cynamonowych, którego Chciuk wspomina w tomie opowiadań. Po wybuchu wojny drohobyczanin starał się wydostać z okupowanej Polski. W liście do Jerzego Giedroycia wspominał:

Ucieczka na nartach na Węgry, fałszywy paszport (gdzie mnie odmłodzono o 3 lata) (...), wojsko we Francji (...), kilkanaście miesięcy więzienia, gestapo i Vichy. Podczas okupacji jeszcze zorganizowałem i wypuściłem w prawdziwej drukarni pismo „Razem”, nielegalnie, redagowałem je potem przez 4 lata do 1947 roku. Od 1943 byłem szefem wydawnictw nielegalnych YMCA - do 1947, później legalnych (...). W Paryżu w latach 1945-6-7 skończyłem Ecole de Journalisme i Ecole des Hautes Etudes Sociales. W grudniu 1947 pojechałem do Polski na 2,5 tygodnia jako delegat PPS na kongres partyjny we Wrocławiu, mając ważny paszport, skróciłem nagle pobyt, bo na przyjęciu sylwestrowym w Prezydium Rady Ministrów przyczepiło się do mnie UB. W Paryżu chorowałem przez 8 miesięcy, o mały włos nie kipnąłem. Potem do 1950 roku pracowałem jako dziennikarz a la pige dla kilku pism polskich i francuskich, dla radia francuskiego, byłem korespondentem „Dziś i jutro” i „Przeglądu Sportowego” 48-49. Nie byłem na etacie, nie byłem urzędnikiem, nie mogła mnie Warszawa odwołać, były różne presje, zmniejszenie zapotrzebowania na reportaże, nędza, fabryka lemoniady, tłumaczenia pokątne, wyjazd do Australii w 1951. Tu były choroby dzieci, żony, moja, trudno o pracę, nieznajomość angielskiego, pracowanie w krematorium (sic!) śmieci, znowu choroba, lanie asfaltów na ulicy, wreszcie kucharz. Po pracy (nielekkiej) piszę i czytam. To wszystko. Podobno ludzie lubią o sobie pisać, mnie to nie bawi. Życiorys banalny. Otarłem się tylko o wiele różnych spraw, od których można dostać zawrotu głowy i przerazić się, wyjechałem więc do Australii. Tu założyłem kabaret lit.-art. - „Wesoła Kookaburra” - idzie to. Kropka (Żongołłowicz 1999, 88).

Życie na emigracji w Australii było dla Chciuka nie lada wyzwaniem. Pisarz podjął współpracę z „Wiadomościami” Mieczysława Grydzewskiego, 
godząc się jednocześnie na mecenat Giedroycia. Ciągła bieda, brak stałej pracy i kolejne nieudane związki z kobietami negatywnie wpływały na kondycję psychofizyczną autora. Chciuk, już jako Andrew Soddell (zmienił nazwisko za namową drugiej żony, Jadwigi Wandy Ernst), jest pisarzem niepewnym wartości swoich utworów. Wcześniej podejmował próby poetyckie, jednak z czasem porzuca poezję, by zająć się publicystyką. W celu pozyskania informacji o australijskiej Polonii odbywa jedenastomiesięczną podróż po Antypodach. Na łamach „Tygodnika Polskiego” w Melbourne drukuje felietony, które nie przysparzają mu sympatii rodaków. I dopiero nagroda „Wiadomości” dla Atlantydy za najwybitniejszą książkę polskiego pisarza wydaną na emigracji w 1969 roku pozwala Chciukowi uwierzyć w swój talent. Sukces wydawniczy osiąga również Ziemia księżycowa, druga część wspomnień z przedwojennego Drohobycza, który autor określa mianem Wielkiego Księstwa Bałaku. Władysław Chciuk (brat pisarza), w liście do trzeciej żony Andrzeja, Basi, wspomina pokrętne losy czterech braci: „Wojna nas rozdzieliła, ale łączy (...) rodzina i Drohobycz. Kto wie, co było ważniejsze. Po tylu latach nie jestem sam pewien. Chyba bałak" (Żongołłowicz 1999, 161). Zatem Drohobycz i specyficzny język - lwowski żargon, to wartości, które w sposób nierozerwalny w utworach pisarza tworzą spójną całość. Jedna nie może istnieć bez drugiej, a razem mają wartość ocalającą pamięć i tożsamość generacji (po)wojennych emigrantów, odnosząc się do wspólnego dla tej generacji miejsca.

Silna więź Andrzeja Chciuka z rodzinnym miastem przypomina symbiotyczny niemal związek Brunona Schulza z Drohobyczem. W Sklepach cynamonowych, kreśląc topografię tego miejsca, ich autor napisał:

Tam, gdzie mapa kraju staje się już bardzo południowa, płowa od słońca, pociemniała i spalona od pogód lata, jak gruszka dojrzała - tam leży ona, jak kot w słońcu, ta wybrana kraina - to miasto jedyne na świecie (Schulz 1997, 217).

Co więc zadecydowało, że - według opinii Chciuka - ów „uroczo prowincjonalny i śmieszny w swej poczciwości" Drohobycz dla wielu jego mieszkańców stał się „jedynym na świecie” (Chciuk 2002a, 7)? Miejsca i ludzie - tylko tyle i aż tyle. Tym, co stanowi o wyjątkowości miasta, jest niewątpliwie jego wieloetniczność. Warto więc spojrzeć na wspomnieniową twórczość Chciuka w kontekście zjawisk pogranicznych, które na dobre zagościły w badaniach literackich, lecz wciąż budzą kontrowersje i są przedmiotem żywych dyskusji.

Tadeusz Bujnicki w Refleksjach oliteraturze kresowej i pograniczu dowodzi, że, posługując się terminem pogranicza, „zwykle zakładamy, iż dotyczy ono jakiejś bliskości, niewielkiej odległości od linearnie wyznaczonej granicy. Pogranicza lokuje się po obu jej stronach, zajmując określone, chociaż niezamknięte, miejsce w przestrzeni" (Bujnicki 2011, 201). Paradoksalnie więc pojęcie „pogranicza”, słowotwórczo pochodzące od "granicy” (linii), odnosi się do przestrzeni otwartej, o nieostrym i niejednorodnym 
charakterze. Idąc w ślad za badaczami zjawisk pogranicznych, należy się zgodzić z tym, że kategoria „pogranicza” konotuje formułę przestrzenności fizycznej, geograficznej, realnej. Jednak rozszerzenie znaczenia o jego kulturowy aspekt rzuciło nowe światło na pojmowanie pograniczności, a nade wszystko poszerzyło horyzonty interpretacyjne pogranicznego dyskursu. Pogranicze kulturowe, jak słusznie zauważa Bujnicki, nie może być tożsame z jego geograficznym (tradycyjnym) odpowiednikiem. Pierwsze ujęcie zakłada bowiem współistnienie, różnorodność, obecność wielu kultur, podczas gdy drugie odnosi się do życia pogranicznego, egzystencji przy granicy. Wykorzystując ten termin na gruncie literatury (kultury), nie sposób pominąć zagadnienie Kresów. Jednakże opisywanie kulturowych zjawisk pogranicznych z perspektywy dyskursu kresowego przestaje wystarczać lub więcej - znacznie zawęża sposób ujęcia omawianego zagadnienia. Przejście od kresów do pogranicza, jak słusznie sugeruje Krzysztof Zajas,

jest znaczące nie tyle terytorialnie, ile antropologicznie. Kresy były nasze, a teraz należą do Innych, podczas gdy pogranicze jest wspólne (...) zamiast straty, mamy wspólnotę terytorialną, historyczną, kulturową, a nawet językową (Zajas 2009, 214-215).

W tym rozumieniu pograniczny Drohobycz Chciuka jawi się jako etniczny tygiel lub - jak chciał Marian Hemar - „półtora miasta” ze społecznościami: żydowską, polską i ukraińską. Autor Atlantydy w swojej drohobyckiej dylogii wiele razy podkreślał wzajemną koegzystencję różnorodnych narodowości, bo jak pouczał małego Jędrka (narratora-bohatera opowieści) ojciec:

wszyscy ludzie są jednakowi (...) Każdy chce żyć, chce jeść, pić, spać, kochać i być szczęśliwym, każdy chce być wolnym, u siebie, boi się strachu, choroby, przemocy (...). Są porządni Niemcy i źli Polacy (...). To samo zobaczysz - jak dorośniesz - u Niemców, Żydów, Węgrów, w każdym narodzie... (Chciuk 2002a, 88).

Jednak lektura drohobyckich utworów Andrzeja Chciuka nie pozwala nam do końca zgodzić się z obietnicą tej wielokulturowej idylli. Podobne stanowisko przyjmuje Jan Sowa w swojej pracy Fantomowe ciało króla. Autor patrzy na kresy z postkolonialnej perspektywy. Według niego dawny sarmacki mit kresów powraca w międzywojniu, kiedy Rzeczpospolita po raz kolejny konstytuowała się jako autonomiczne państwo (Sowa 2012, 496). Sytuacja ta skutecznie stymulowała projekt „wymazywania wszelkich antagonizmów” w wielu miejscach pogranicza. Autor twierdzi, że „harmonijne współżycie skolonizowanych i kolonizatorów" to fikcja (Sowa 2012, 513). Mówi o tym również wspomniany już Krzysztof Zajas, poddając krytycznej analizie relacje "swojego" wobec „Innego”. Według niego próby nawiązania kontaktów z Obcym służą jedynie zaspokajaniu własnej próżności. Ten pozorny dialog daje szansę projekcji „ego” pisarza, a opowieść o Innym tak naprawdę staje się monologiem na swój temat: „Mówimy o wielokulturowości, ale szukamy takich jej odmian, które powiedzą coś o nas, a konkretnie to, co chcemy usłyszeć (...), co już istniało jako nasza perspektywa 
- wielokulturowa, ale nadal polska" (Zajas 2009, 218) - konkluduje autor i trudno się z nim nie zgodzić.

Andrzej Chciuk z powodzeniem obiera tę technikę odautorskiego, subiektywnego punktu widzenia. Powierzając nam bowiem tajemnice Wielkiego Księstwa Bałaku, tak naprawdę snuje narrację o sobie, zaś próba zbliżenia się do Innego w konsekwencji staje się iluzją. $\mathrm{W}$ ten oto sposób wielokulturowość z realnego doświadczenia zostaje przeniesiona w sferę mitu. Pisarz doskonale zdaje sobie z tego sprawę. Jego słowa: „Normalna ludzka atrofia pamięci, astygmatyzm wspomnień i nasza skłonność do upiększania i mitologizowania ich na starość..." (Chciuk 2002a, 53) dowodzą, że autor Atlantydy uzurpuje sobie niejako prawo do zniekształcania wspomnień. Trudno jednoznacznie dać wiarę Chciukowi, który autorytatywnie zapewnia o zgodnym współistnieniu wieloetnicznego Drohobycza. Niejednoznaczność oceny nastrojów społecznych wymaga zatem szczegółowego rozpoznania stosunków między ludźmi zamieszkującymi miasto. Kwestię te podejmuje Chciuk w reportażu z pobytu w Izraelu:

najlepiej jest pisać o sprawach, które się dobrze zna (...). Bo oto przez moje miasto, jego mikrokosmos i powiązania ludzkich losów widzimy typowy wycinek historii (...) z wszystkimi zbrodniami i koszmarami naszych czasów, z ludzkim cierpieniem, bohaterstwem i Pięknością człowieka u swych braci Żydów, Ukraińców i Polaków, synów tej ziemi, skąd wszyscy pochodzimy i do której miłość u ogromnej ilości Żydów nie zbladła pomimo licznych cierni i krzywd, pomimo zagarnięcia ich już w inną przyszłość (Chciuk 1972, 8).

Chciuk zdaje sobie sprawę z różnorodności miasta swojego dzieciństwa, co dla „nędznej prowincji” mogłoby być szansą, a w najgorszym wypadku symbolem, znakiem rozpoznawczym ${ }^{1}$. Wydaje się jednak, że jego współczucie dla „braci Żydów” jest tyleż pompatyczne, co powierzchowne. Podobny ton towarzyszy zresztą pisarzowi, kiedy przywołuje wspomnienia z przedwojennego Drohobycza. Jak wytrawny przewodnik, Chciuk oprowadza nas po swoim mieście. Szczególnie interesują go miejsca, które zapamiętał z dzieciństwa - obce, zakazane. Ich obecność młody chłopak dostrzega, lecz nie bardzo rozumie. Razem z nim odwiedzamy gimnazjum żydowskie Blatta, dom starców prowadzony przez Gminę Żydowską przy Sobieskiego czy słynną dzielnicę żydowską Łan. Mamy możliwość obcowania z handlarzami ryb i księgarzem Segalem, spolonizowanymi Langermanami, sąsiadami Chciuków i okolicznym dziwakiem, handlarzem starzyzną. Autor Ziemi księżycowej zapoznaje nas ze Stieflami, „cichymi Żydami” wynajmującymi mieszkanie w domu przy ulicy Polnej 8, starym rabinem doktorem Schreierem, wykładowcą religii żydowskiej, który wstawił się za Andrzejem, gdy ten przysporzył sobie kłopotów podczas gry w karty na lekcji religii. Uczestniczymy $\mathrm{w}$ pogrzebie rabina Wagmana, a nawet

\footnotetext{
Zagadnieniem wielokulturowego miasta zajmowali się m. in.: Zajas Krzysztof, 2011, Kresy skreślone, czyli o polskiej wielokulturowości, w: Gawliński S., Siewior D. (red.), Dwie dekady nowej (?) literatury 1989-2009, Kraków, s. 211-224 oraz Dąbrowski Mieczysław, 2001, Swój/ Obcy/Inny, Warszawa, s. 56-74.
} 
w korowodzie żydowskich kolędników biegających po polskiej dzielnicy miasta - Wójtowskiej Górze. Autor chwali się przed nami znajomością z Brunonem Schulzem, którego dość naiwnie przedstawia jako „płaskiego” filozofa, masochistę egzaltującego się wypadkami w mieście. W rozdziale Atlantydy zatytułowanym Ślepe na mecze nie chodzu wspomina mecz Junaka - lokalnego klubu sportowego - z Ukraińcami. Szczególnie dużo miejsca poświęca rozentuzjazmowanym kibicom, wśród których znajdowali się również Żydzi. Z niezwykłą precyzją odtwarza epizod, kiedy to

Mariańciu Wilk, który, by przerwać przegrywany przez Junaka mecz, na boisko wpadł przebrany za Żyda i z doprawionymi pejsami, i w pożyczonym chałacie zaczął lać sędziego parasolem, by odium spadło na Żydów (Chciuk 2002a, 30).

Jak słusznie zauważył Arkadiusz Bagłajewski (Bagłajewski 2014, 93), Chciuk był świadom międzywojennego dyskursu antysemickiego i starał się go uniknąć. Dlatego też opis znieważenia żydowskiej szaty przez jednego z kibiców zostaje zrównoważony przez nie do końca trafnie użyty humor. Poza tym pisarz dodaje, że ten sam

Mariańciu z Błonnej ulicy w czasie okupacji chował u siebie Żydów, dawnych oponentów (...). A mały Strutyński, choć krzyczał na meczach okropnym głosem: bij Żyda!, zginął potem z całą rodziną, rozstrzelany przez Niemców za przechowywanie kilku kolegów Żydów (Chciuk 2012a, 93).

W innym rozdziale Atlantydy Chciuk poświęca sporo miejsca handlarzowi starzyzną, Żydowi Chaimkowi, który już wyglądem zwracał na siebie uwagę: „chałat, broda, lisia czapa i śmieszne wówczas dla mnie żydłaczenie" (Chciuk 2012a, 82). Chaimek jest kwintesencją inności, uosobieniem Obcego, spotkanie z którym mogłoby być dla otoczenia sprawdzianem z moralności, egzaminem z tolerancji. Chciuk z rozbrajającą szczerością relacjonuje, w jak świadomy i zaplanowany sposób polscy gimnazjaliści upokorzyli Żyda, popychając go i niszcząc jego marny dobytek:

Chaimek jęczał tylko i z rozwianymi połami chałata biegł za wózkiem. Tam upadł i płakał, trzymając głowę w dłoniach. Ten zawodzący jęk człowieka do ostatnich granic nieszczęśliwego słyszę nawet teraz (Chciuk 2012a, 83).

Można by ten incydent zaliczyć do dziecięcych wybryków, jednak Katarzyna Olszewska $\mathrm{w}$ artykule poświęconym antysemityzmowi zwraca uwagę na antyżydowskie zachowania, które rozpowszechniły się wśród dzieci (Olszewska 2012). Zjawisko to, zazwyczaj bagatelizowane i uważane za nieszkodliwe, mogło w formie utajonej dojrzewać, by w końcu uzyskać społeczną sankcję. Tymczasem - jak sugeruje autorka artykułu - dziecięce wybryki były odzwierciedleniem nastrojów świata dorosłych. Smutną historię Chaimka kończy Chciuk w typowy dla siebie sposób. Tym razem w roli moralizatora i poniekąd sumienia rodziny występuje matka autora, która po konfrontacji z poszkodowanym oznajmiła synowi, że Chaimek jest bardzo nieszczęśliwy i że jest takim samym człowiekiem jak inni. Tani i mocno 
zdewaluowany to argument. Podobny przykład polsko-żydowskich antagonizmów, które Henryk Grynberg wspomina w cytowanym na początku zbiorze Drohobycz, Drohobycz, znajdujemy w opowiadaniu Frelichowie i oba rynki z Ziemi księżycowej. Tym razem jednak autor opisuje sprzedaż karpi prowadzoną przez polskich studentów przed Bożym Narodzeniem, co stanowiło konkurencję dla żydowskich handlarzy z Małego Rynku: „kupcy żydowscy (...) obserwowali nas z żalem i złością, albowiem nasze sprzedawanie ryb pozbawiło ich utargu".

Cytowany już Arkadiusz Bagłajewski w innym miejscu swojego artykułu pisze:

świat Chciuka to (...) kraina zgodnego współżycia narodowości: polskiej, żydowskiej i ukraińskiej. Owszem, narastają animozje narodowościowe, ale są tu wyraźnie odsuwane na dalszy plan, łagodzone życzliwą aurą humoru (Bagłajewski 2014, 87).

Nie nazwałbym Chciuka antysemitą, jednak może irytować polonocentryczny punkt widzenia Innych, a także skłonność pisarza do konfabulacji. Zwrócił na to także uwagę Jerzy Giedroyc, którego słowa przytacza w biografii autora Atlantydy Bogumiła Żongołłowicz. W Chciuku redaktora „Kultury” szczególnie denerwuje skłonność do przesadnych pochwał, niemal panegiryków, tendencja do przerysowywania, a nawet zniekształcania niektórych sylwetek oraz „skłonność do szarży” (Żongołłowicz 1999, 155). Chciuk doskonale orientuje się w niesprzyjającej Żydom polityce państwa polskiego. Co prawda - jak czytamy w Słowniku schulzowskim „Drohobycz w okresie międzywojennym był miastem, w którym nie dochodziło do poważniejszych konfliktów narodowościowych" (Bolecki... 2003, 23), jednak sam autor w postrzeganiu Innych powiela utrwalany przez lata stereotyp. Podczas swojej wędrówki po dzielnicy żydowskiej zastanawia się: „nie byłem pewien, czy to nie grzech patrzeć na Żydów, których przodkowie zamordowali Chrystusa" (Chciuk 2002a, 110). Narrator, przyjmując perspektywę dziecka, wyraźnie deprecjonuje Żydów, uznaje ich za niższą, a co za tym idzie - gorszą nację. Młody Jędrek powtarza sądy dorosłych, które wzmacniają tylko mit złego Żyda. Taki sam pejoratywny jego wizerunek zawiera opowiadanie Pierwsze boje, w którym autor zdradza kulisy początku swoich dziennikarskich prób (Chciuk 2002z, 123-139). Chciuk wspomina między innymi harcerskie pismo „Włóczęga”, którego był redaktorem naczelnym. Chwali się, że profil gazety odpowiadał i antysemitom, i Żydom, i sanacji. Jednak sposób portretowania redaktora jednej z drohobyckich gazet - Henryka Szpringera - jest jednostronnie negatywny: "mały, krzywy, zezowaty i milczący” (Chciuk 2002z, 125), a do tego odważył się krytykować czasopismo wydawane przez młodych harcerzy. To był już wystarczający powód, by dać mu nauczkę. Swoją dezaprobatę wobec Szpringera wyraził także starosta drohobycki; głównym powodem było żydowskie pochodzenie redaktora. W innym opowiadaniu Dobromilska przygoda Antka Chciuk udowadnia, jak hermetyczne było środowisko 
ortodoksyjnych Żydów, którzy również wykazywali niechęć do obcych. Tym razem to Żydzi potraktowali Polaków jak intruzów, którzy przeszkadzali modlącym się w synagodze. Osobną kwestię stanowi powód, dla którego brat autora ze swoim kolegą przekroczyli próg świątyni. Z pewnością nie zrobili tego z pobudek religijnych.

Katarzyna Weinper, analizująca przestrzeń Drohobycza w prozie Schulza, wyróżniła jej różne aspekty (Weinper 2009, 335-345). W przywoływanych wspomnieniowych utworach Chciuka z reguły mamy do czynienia z przestrzenią fizyczną, która oddaje specyfikę miasta pogranicza kulturowego. Bardzo dobrze została ona uwidoczniona we wspomnieniu wędrówki po Łanie, dzielnicy Drohobycza zamieszkałej przez społeczność żydowską (Chciuk 2002a, 108-122). Narracja prowadzona z punktu widzenia bohatera wpływa na egocentryczność owej przestrzeni ze zmieniającym się centrum [odczuwania] - małym Jędrkiem. W sposób typowy dla prozy wspomnieniowej autor konsekwentnie postrzega rzeczywistość z punktu widzenia dwóch narratorów: wspomnianego dziecięcego, nieświadomego siebie i przeszłości oraz człowieka dorosłego, który z bagażem doświadczeń, wyczuciem taktu, a co za tym idzie, dystansem odnosi się do poruszanych zagadnień. Jest on świadom konsekwencji wynikających na przykład z antysemityzmu. Oswojona przez młodego bohatera przestrzeń ma układ koncentryczny, otwierający przestrzeń w porządku rosnącym: pokój chłopca (strych), mieszkanie rodziców, lokale sąsiadów, podwórko i najbliższa okolica, ulica Polna i Wójtowska Góra, rynek i corso, gimnazjum. Łan należy do przestrzeni obcej - tyleż egzotycznej, co fascynującej. Jej odmienność wyraża autor kwiecistymi epitetami rodem z Schulza: „rezerwat niezwykłej inności”, „fascynująca niezwykłość najzwyklejszych spraw”, „woń żydowskiej małomiasteczkowej nędzy”, „przepastne oceany inności wnętrz". Nośnikiem tego intrygującego go świata są ludzie zamieszkujący tę dzielnicę - Chciukowe „typy i typki” lub - mówiąc prościej - ciekawi ludzie: czapnik Josefe Bante, wariaci Abrumku i Benio Spitz, pomocnik rabina Simche Piórko. Po wejściu do Łanu tak dobrze opanowane kompetencje przewodnika bohater przekazuje Teo Langermannowi, synowi żydowskich sąsiadów Chciuków.

Ziemię księżycowa rozpoczyna zdanie: „Ciągle ta dwoistość. Jestem tu i żyję tu (...). Ale ileż razy (...) jestem tam?” (Chciuk 2002z, 7). Ta dychotomiczna perspektywa widzenia miejsc i ludzi towarzyszy pisarzowi w obu częściach opowieści o Wielkim Księstwie Bałaku: „Mój Drohobycz, śmieszny i piękny, mały i wielki, okropny i jedyny z całym jego i moim kosmosem..." (Chciuk 2002a, 158). W innym miejscu pisarz ekscytuje się: „nareszcie coś niezwykłego stało się w naszym ukochanym, lecz bardzo durnym mieście..." (Chciuk 2002a, 146). Ta ambiwalentna perspektywa - jak już wcześniej zauważyłem - towarzyszy również Chciukowi w ocenie bieżących wydarzeń, których jest jednocześnie uczestnikiem i świadkiem; szczególnie jeśli rzecz dotyczy polsko-żydowskich relacji. W tym kontekście ciekawe może 
wydać się zdanie z Atlantydy: „Ech, życie, co ty z nami robisz?” (Chciuk 2002a, 150). A więc to nie człowiek kieruje swoim losem i w związku z tym nie do końca ponosi odpowiedzialność za własne czyny. Chciuk przekonuje, że jest się tylko marionetką w "teatrze życia”, a działaniem losu na ludzkie wybory można usprawiedliwić każdy, nawet najbardziej haniebny czyn.

W drohobyckiej dylogii nie brak też przykładów szlachetnych postaw Polaków wobec narodowości żydowskiej. Drohobycki dziekan, ksiądz doktor Kazimierz Kotula, uratował wielu Żydów i udzielał chrztu, by ratować ich przed śmiercią (Chciuk 2002a, 22). Podobnie Zajączkowscy z ulicy Śnieżnej i stary Worosiński. A żona majora Wojska Polskiego, posłanka ziemi drohobyckiej, Laryssa Chomsowa w czasie okupacji niemieckiej ocaliła życie 153 Żydom (Chciuk 2002z, 121-122). Swój protest przeciwko antysemityzmowi Andrzej Chciuk wyrażał w polonijnej prasie w Australii. Jego opowieści o stosunkach narodowościowych w Drohobyczu zbiegają się ze wspomnieniami licznych drohobyczan, którzy nie przypominają sobie większych konfliktów narodowościowych, pomimo wieloetnicznego charakteru tego miasta. Żydzi, Ukraińcy, Polacy, ale także Niemcy, Ormianie, Austriacy i inni za czasów II Rzeczypospolitej żyli w pozornej symbiozie. Odmienne zdanie prezentuje Henryk Grynberg, wspominając przypadki znęcania się nad żydowskimi dziećmi lub powołując się na ślady antysemityzmu wśród nauczycieli, studentów i przedsiębiorców. Być może najbliżej prawdy historycznej był Kazimierz Wierzyński, który w wierszu Lekcja konwersacji pisał:

Nie mów o Polakach i Żydach

To pole minowe.

Nie mów o Polakach i Ukraińcach,

To pole minowe.

Nie mów o Polakach i Czechach,

To pole minowe...

(Wierzyński 1991, 507).

Z kolei Ukraińcy w utworach Andrzeja Chciuka zostali przedstawieni epizodycznie. Funkcjonują na zasadzie stałego, neutralnego, a czasami wrogiego tła. Pomijając szczegóły, autor sygnalizuje początek dojrzewania świadomości narodowej Ukraińców, wzmiankując poniekąd o niektórych objawach ukraińskiego nacjonalizmu. Z pewnością ta część społeczeństwa jest mniej atrakcyjna od galicyjskiej mieszanki narodowościowej. W rozdziale Atlantydy zatytułowanym Szczybanie liści z drzewa poznania młodych bohaterów najbardziej intrygują Ukraińcy. Dzieci nie kryją zaskoczenia, że ci nie różnią się niczym od innych ludzi: „To czemu nasi kuzyni z Katowic tak się dziwili, gdy pierwszy raz zobaczyli przez okno Ukraińców?" - pytali (Chciuk 2002a, 85). Prawdopodobnie ich społeczność nie była tak ekspansywna jak żydowska, a folklor - nie tak spektakularny jak wyznawców judaizmu. Stereotyp w postrzeganiu Żyda czy Polaka pozostawiał naddatek wiedzy na ich temat, dlatego percepcja tych narodowości była dla bohaterów czymś naturalnym. W charakterystyczny dla autora sposób, po kąśliwej 
uwadze na temat obcych, pojawia się komentarz tonujący krytyczną opinię, jednak w roli moralizatora tym razem występuje ojciec Chciuka, w którego usta wkłada autor naukę o równości wszystkich ras i narodowości. Trudno się z tym nie zgodzić, kiedy wspomina historię Hołówki, który został zastrzelony przez ukraińskiego terrorystę. Pejoratywny stosunek do Ukraińców wyraża choćby to zdanie: „...tragizm tej śmierci wyczuwali nawet niektórzy Ukraińcy, nie tylko Polacy i Żydzi" (Chciuk 2002a, 104). Hołówko, jako symbol polsko-ukraińskiego pojednania, ukazuje klęskę marzeń o zgodnym współistnieniu tych narodów. Przekonanie Polaków (podszyte megalomanią) do uzurpowania sobie prawa do zamieszkiwania tej ziemi wyrażają słowa: „Dotychczas na naszej ziemi mieszkaliśmy razem - Ukraińcy, Żydzi i Polacy - a tu nagle ktoś nas, Polaków chciał stąd wyrugować" (Chciuk 2002a, 105). Andrzej Chciuk, podobnie jak przy ocenie Żydów, tym razem tonuje obraz Ukraińców, których wszyscy się boją: „Prawdą jest, że Ukraińcom w Polsce należała się autonomia, że nie mieli swojego obiecanego uniwersytetu, (...) że Polska wobec nich była często głupia..." (Chciuk 2002a, 106). Jeszcze inny przykład animozji narodowościowych zawiera opowiadanie Historia $z$ loteria fantową. Autor, będąc dowódcą drużyny zuchów, wracał z nocnej eskapady po lokalnym festynie, kiedy został napadnięty i pobity przez Ukraińców. Powodem tego były nieuczciwe zasady loterii fantowej, w której główna nagroda - akordeon - spodobała się hersztowi grupy Ukraińców: „My ciebie, dziadu, tu teraz zatłuczemy, Lachu parchaty, za tę harmonię” (Chciuk 2002z, 38). Spotkanie na moście mogło mieć bardziej poważne konsekwencje niż strach i rozbita głowa bohatera wspomnień. Tradycyjnie już - lwowskie spotkanie po latach Chciuka ze swoim dawnym oprawcą nie ma wcześniejszej dramaturgii. Adwersarze zachowują się jak przyjaciele, a nad skomplikowaną historią pobrzmiewa serdeczny śmiech obydwu. Pisarz permanentnie odsuwa na bok coraz wyraźniejsze konflikty narodowościowe, łagodząc je humorem, co zresztą może irytować czytelnika.

Przyjęcie przez Chciuka takiej strategii ukazywania obcych stało się znakiem rozpoznawczym autora Atlantydy. Cokolwiek by mówić o takcie i poprawności politycznej w ujmowaniu tematu wielonarodowości, pisarz z życzliwością przygląda się ukraińskim sąsiadom. Docenia profesjonalizm inżyniera Chomyszyna, którego stryj był biskupem grekokatolickim w Stanisławowie, i zasługi dyrektora Baraniuka dla ukraińskiego gimnazjum. Choć wielokrotnie niepochlebnie wypowiada się o matematyku Krawczyszynie, który zresztą też nie pałał sympatią do ucznia Jędrka, lecz już z rozrzewnieniem wspomina szkolnego kolegę Michała Czepowskiego, Ukraińca, który był obiektem drwin owego nauczyciela. Wśród licznych lokatorów domu Chciuków znajdowali się też Maksymowiczowie, „mili Ukraińcy”. Z rozbrajającą szczerością autor wspomina, że „z dwojga złego bowiem woleli już Ukraińcy dać zarobić Polakom" (Chciuk 2002z, 12) niż Żydom. Zdarzało się jednak, że przedstawiciele wszystkich trzech narodowości jednoczyli się. Tak było wobec bolszewików, wspólnego wroga, który 
pierwszego w Drohobyczu rozstrzelał Ukraińca Myszkę, komunistę. Chciuk z przejęciem opisuje pobór mężczyzn do wojska. Z końcem sierpnia 1939 roku i rekrutom, i odprowadzającym ich polskim lub ukraińskim rodzinom towarzyszyły podobne uczucia:

Obok nas stali Żydzi, Ukraińcy i Polacy, ludzie znani mi dobrze albo z widzenia, albo zupełnie nieznani (...) ktoś wreszcie pomimo upału zaczyna śpiewać: „W dzień deszczowy i ponury...” A wszyscy to podejmują, wszyscy to śpiewają, Żydzi „w dżeń", Ukraińcy „w deń deszczowyj i ponuryj”, ale wszyscy myślą to samo, może uda się, że powróci zdrów i zobaczy miasto Drohobycz (Chciuk 2002z, 96-97).

Innymi wydarzeniami w mieście, które czyniły jego mieszkańców wspólnotą, były mecze lub pogrzeby. Opisywane w Ziemi księżycowej zmagania drużyny hokejowej drohobyckiego Sokoła z przemyskim Czuwajem zgromadziły na widowni Polaków, Żydów i Ukraińców, którzy razem kibicowali zawodnikom z Drohobycza. Chciuk w narrację meczu wplata liczne dygresje na temat kibiców: między innymi historię nacjonalisty ukraińskiego Sławka, który „twierdził, że Polacy całą terminologię naukową wzięli z ukraińskiego”, a język ten jest „najstarszym językiem świata” (Chciuk 2002z, 114). Wspomina również metropolitę Szeptyckiego, Ukraińca z wyboru, który z narażeniem życia w katedrze św. Jura uratował wielu oficerów polskich. Chciuk w optymistycznym, charakterystycznym dla siebie tonie konkluduje:

Lecz zawsze w tym kraju wielu narodów i kultur, wielu orientacji i złudzeń, wielu wzajemnych krzywd i wiarołomności, win, oskarżeń i przesądów, nie brak było w najciemniejszej nocy i prawdziwej braterskiej miłości, i prawdziwej ludzkości nieraz wprost monumentalnej, aż ocierającej się o świętość (Chciuk 2002z, 12).

Z zaprezentowanych przykładów wynika, że Andrzej Chciuk w drohobyckiej dylogii kreśli obraz Księstwa Bałaku w sposób ambiwalentny. Z jednej strony nie pomija zdarzeń, które rodziły późniejsze antagonizmy i w konsekwencji doprowadziły do rozpadu wielokulturowej Atlantydy, z drugiej zaś ów niewygodny realizm równoważy typowym dla gawędy humorem bądź przywoływaniem zasług opisywanej grupy dla reszty społeczeństwa. W ten sposób Chciuk wpisuje się w ideę „pogranicza”, które charakteryzuje swoista niejednorodność - odrębność, ale i wymiana, oddzielenie, lecz również przenikanie (Próchnicki 2012, 35-51). Tę dwoistość pisarz dostrzega także w istocie prowincji, która „daje niby spokój i ciszę, ale człek ciągle jest jakby za szybą (...) wystawy" (Chciuk 2002a, 50) lub - jak wspominałem wcześniej - w obrazie miasta. Autor zastanawia się: „Ale komu ja zasunę bajer, że Drohobycz był taki piękny? Nie zasunę, bo nie był, bo to miła i nudna, brudna i urocza, śliczna i nędzna prowincja, tyle że byłem tam młody" (Chciuk 2002z, 54). Złudzeń o wyjątkowości tego miejsca pozbawia pisarza po latach mecenas Chmielowski w Melbourne: „pan pisze o tym swoim Drohobyczu jak o Paryżu pańskiej młodości, ale to była okropna żydowsko-ukraińska dziura, pan to sobie wszystko idealizuje..." (Chciuk 2002z, 56). Słowa te mogą odnosić się do wrażeń Alfreda Döblina z wędrówki po 
międzywojennym mieście. A więc najpierw idealizacja, a później profanacja tej idei stają się świadomym zabiegiem Chciuka, projekcją jego subiektywizmu, znakiem pamięci. Motywy „zatopionej Atlantydy” i nieosiągalnej, wyrażonej paradoksem „Ziemi księżycowej” konotują niejako idylliczny charakter świata, narzucają potrzebę idealizacji. Jednak Arkadia Chciuka nie jest krainą mlekiem i miodem płynącą. Owszem, stanowi ona raz na zawsze utraconą „geografię serdeczną”, ale istnieje w ściśle określonej przestrzeni i czasie, który zarówno ocala, jak i niszczy jej tożsamość.

Ale nie było owo Księstwo Bałaku wyłącznie jakąś Arkadią, pełną wiecznej szczęśliwości i uroku. Nędza czasem tu aż skwierczała, nie bajerujmy się barwikiem i perspektywą wspomnień, które wszystko uróżowiają i przemeblowują proporcje na milusie i śliczne (Chciuk 2002a, 14).

Arkadia Chciuka to świat podzielony, pęknięty, niespójny, o dychotomicznej strukturze (Czaplejewicz 1987, 74). Wyróżnia się w nim swoiste napięcie między tym, jak jest, a jak mogłoby być.

Kategorią, która u pisarza zajmuje miejsce pierwszorzędne, jest pamięć wpływająca na kształt i jakość przechowywanego we wspomnieniach świata. Pasjonuje ona Chciuka i prześladuje zarazem, staje się również stymulatorem mityzacji ludzi i miejsc. Nadmierne zaufanie do własnej pamięci sprawia, że autor Atlantydy wpisuje się w typową dla dyskursu pogranicznego konwencję. Opisywany świat nasyca subiektywizmem, postrzegając go tylko $\mathrm{z}$ jednego punktu widzenia - $\mathrm{w}$ tym przypadku bohatera Jędrka. Trzeba dodać, że czyni to dość konsekwentnie. Taki sposób widzenia świata pozbawia bohatera weryfikacji jego sądów (nie licząc opinii o Drohobyczu kilku australijskich znajomych autora), co również wzmacnia wymiar mitotwórczy opowieści o Bałaku. Pamięć więc, jak słusznie dostrzega Arkadiusz Bagłajewski, jest „,budulcem prozy wspomnieniowej na zasadzie Bergsonowskiej rekonstrukcji" (Bagłajewski 2014, 85). Na ten aspekt zwróciła również uwagę Maria Delaperrière, która w swoich pracach badała zależności między historią a literaturą (Delaperrière 2013, 49-60). Według niej pamięć jest zjawiskiem ciągle aktualnym, które niejako spina klamrą „doświadczenie przeszłości” z „wieczną teraźniejszością”. Autorka słusznie podkreśla, że „miejsce pamięci” nie wiąże się jedynie z geografią czy topografią miejsc przywołaną w utworze; jego zakres jest znacznie szerszy, obejmuje bowiem ogół materialnych i niematerialnych znaków i śladów uobecnionych w pamięci zbiorowej lub indywidualnej. Autor Ziemi księżycowej wykazuje niezwykłą dyscyplinę, by zwerbalizować przywołane wspomnienia, z katalogową wręcz precyzją opisać wszystkie „typy i typki” czy miejsca Drohobycza i jego okolic. Rzeczywiście, jak sam zauważył, „stawanie się pamięci” to dla niego sprawa pierwszorzędna. Epitety: „cudne bałaku”, „zatopiony przylądek dobrej nadziei”, „zegar słoneczny szczenięcych lat” czy „podręcznik geografii serdecznej” z gruntu już zdradzają tendencję do idealizacji miejsca dzieciństwa autora. Wspomniana Maria 
Delaperrière pisze: „Inną, praktykowaną we współczesnej literaturze drogą poszukiwań jest strategia zanurzenia w przeszłości w zmysłowym kontakcie z miejscem, które było i nadal jest" (Delaperrière 2013, 54). Bez odniesienia do miejsc ukochanych, a zwłaszcza miejsca urodzenia, dzieciństwa, tożsamość człowieka będzie zawsze niepełna. W nawiązaniu do wspomnieniowych tomów Andrzeja Chciuka warto jeszcze raz podkreślić przywoływany już zmysłowy kontakt autora z miejscem, który skutkuje sensualnym charakterem jego prozy.

Zuzanna Wasilewska-Lipke w artykule poświęconym Atlantydzie Chciuka wspomina o „narracji synestezyjnej”, która wyróżnia wspomniany utwór (Wasilewska-Lipke 2005, 112). Autor z proustowskim zacięciem opisuje smaki, zapachy i dźwięki - a więc specyficzną różnorodność materii tamtego świata. Wszystko dla niego jest ważne: zapachy dusznych mieszkań, mgieł, ropy i błota czy gnojówki nieopodal domu; dźwięki ostrzenia noży przez Jasia Kapustę z nieodłącznym wózkiem lub bicie dzwonów po zdobyciu przez Junaka mistrzostwa Ligi Okręgowej; smaki babki wielkanocnej ze smalcem, aromatycznej kawy ze śmietanką, fasolki szparagowej z własnego ogródka w kwaśnym sosie z ziemniakami. Rzeczy ważne przeplatają się z na pozór banalnymi, jednak dla Chciuka wszystkie one są znakami pamięci, czy - jak chciał autor - „nitkami w arrasie”. Przestrzeń fizyczna miasta traci swoje realne kontury w onirycznej, a do azylu-domu przenikają elementy z obcego, nieoswojonego przez bohatera świata. Te wzajemne fluktuacje, przenikanie się przestrzeni i pozorny chaos spisywanych doświadczeń stają się znakami rozpoznawczymi pisarstwa Chciuka (Bagłajewski 2014, 88).

Dyskursowi wspomnieniowemu, uobecnianiu miejsc pamięci towarzyszą jednocześnie nostalgia i afirmacja. Przywoływany już w tekście Jan Sowa dowodzi, że „w nostalgii kresowej dochodzi do szczególnego rodzaju synestezji: czas przyjmuje właściwości przestrzeni i tęskniący podmiot uzyskuje zdolność poruszania się w nim w dowolnym kierunku" (Sowa 2012, 505). Z pewnością ten wymiar tęsknoty za ojczyzną przenika postawę autora Atlantydy, który wykazuje wysoki poziom samoświadomości. Na kartach drohobyckich utworów Chciuk wielokrotnie dawał świadectwo straty swojego miasta, czego dobitnie dowodzi zdanie kończące Atlantydę: „Oj, Boży, Boży, czemu to wszystko tak si stału?” (Chciuk 2002a, 158). Nostalgia, o której mowa, nie jest siłą destrukcyjną niszczącą wartości, które wyznawał autor, lecz przeciwnie - wyznacza mu ona nowe horyzonty, ukierunkowuje w stronę dotychczas niezbadanych przestrzeni. Idealną formą dla tego typu dyskursu jest konwencja gawędy, która zdecydowanie skraca dystans między autorem a jej adresatem. W czasie lektury drohobyckich utworów Chciuka mamy wrażenie, że od dawna należymy do dobrze znanego, oswojonego świata pogranicza kulturowego, współuczestniczymy w jego małych sprawach i wielkich dramatach, a narrator - dzięki swojskiemu bałakowi - przyjmuje rolę dobrego znajomego z najbliższego sąsiedztwa. Formuła 
gawędy, niczym silva rerum, pozostawia u odbiorcy wrażenie nadmiaru miejsc, osób, zdarzeń. Chciuk świadomie nie dba o selekcję opowieści przeciwnie, przywoływane wydarzenia prezentuje nam „na gorąco”, jedno łączy z drugim bez ściśle określonego pomysłu kompozycyjnego. W ten sposób jego historia zyskuje na wiarygodności, a narrator-gawędziarz traktowany jest przez odbiorców jak najbardziej serio. Bardzo często przyjęta perspektywa dziecięcego narratora pozostawia ślad w postaci naiwnej percepcji świata zewnętrznego, niezaskakującego, przewidywalnego autokomentarza. W opowiadaniu Arras padają słowa:

ludzie potrzebują takich smutno uśmiechniętych książek, aby się w ich kartach jak lustrze przejrzeć, by zobaczyć swoje tamtejsze Drohobycze, upiększone może ciut tęsknotą, ale i osadzone na własnym miejscu w sercu przez całkowitą szczerość (Chciuk 2002z, 94).

Istotnie, autor wielokrotnie wyraża troskę o czytelnika, jakby chciał mu się przypodobać. Osobną kwestią jest fakt, że pisarz uzurpuje sobie skłonność do upiększania swojego życiorysu, widzenia kilku rzeczy i spraw na raz. Dlatego zgadzam się z przywołanym przez Edwarda Kasperskiego Henrykiem Markiewiczem, który w dyskursie kresowym wyodrębnił stałą obecność "cech naddanych” (Kasperski 2007, 102). Podobną tendencję $\mathrm{z}$ pewnością można dostrzec $\mathrm{w}$ utworach prozatorskich Chciuka. Utratę ojczyzny autor próbuje zrekompensować różnorodnością stylu, kwiecistością języka, luźną kompozycją czy wielością konwencji, jak gdyby dawał sobie prawo do absolutnej wolności w języku właśnie. Używane przez pisarza określenie „arrasu”, „kalejdoskopu” czy „fotoplasykonu” wydaje się jak najbardziej trafne. Zagęszczenie treści najłatwiej oddać mnogością rozwiązań stylistycznych, przez co w dylogii realizuje się swoiste decorum. Arras Wielkiego Księstwa Bałaku obejmuje ludzi, których połączył Drohobycz. Chciuk potwierdza: „Moja ojczyzna-swojszczyzna (...) nigdy nie była jednojęzyczna i jednoplemienna (...). Polska to (...) wspólnota kulturowa i współlosy naszych sąsiadów i wspólny ślad po nich" (Chciuk 2002z, 30). Autor jak w kalejdoskopie patrzy na ludzi, przywracając im jednocześnie miejsce w Księstwie Bałaku. W ten sposób proza wspomnieniowa twórcy Atlantydy ma siłę ocalającą od zapomnienia.

Niepodważalną wartością drohobyckich wspomnień jest język Chciuka, żywy bałak, który wykorzystuje zasoby potocznej mowy. Autor „podsłuchuje" swoich bohaterów i pozwala im snuć własne narracje - często kalekie, niedoskonałe, lecz przez to jakże wiarygodne. Pisarz chętnie przytacza żargon szkolny, nie jest mu obcy język ulicy, urzeka go słownictwo ludzi prostych, na przykład grabarza-,„pogrzebacza” Gintera: „- Jo, ja, panie Edziu, i panu współczujim, ali my to aligancko raz-dwa załatwimy" (Chciuk 2002a, 28), szewca Pszeniczki: „No, jak si smarkateria uczy? Bo jak ni, to właśnie wyrzuciłym czeladnika i powiedziałym mu: chebaj siroto, niech cię moje pienkne oczy wiency nie widzu" (Chciuk 2002a, 99-100) czy Jasia 
Kapusty, który ostrzył w Drohobyczu noże i nożyczki: „Bękarty, si przejmjei psem, a tu człowiekowi ganz zaschło na pieprz w gardli. Ta wy by coś przynieśli i dla mnie" (Chciuk 2002a, 77). W typowy dla siebie sposób pisarz nie stroni od kolokwializmów i regionalizmów: „Cie cholera: mam grypę, ona ma mnie (...). Zadzwoniłem do badylarza...” (Chciuk 1973, 6). Nieskrywaną namiętnością Chciuka, czemu dawał wyraz w cytowanej dylogii, były mecze piłkarskie, podczas których specyficzny żargon wyróżniał wszystkich kibiców, dodawał głębi lokalnemu kolorytowi. Czasami Chciuk przytacza bałak wprost na zamówienie czytelników. W felietonie Lwowskie naciaganie przywołuje zapamiętane $\mathrm{z}$ dzieciństwa dialogi, $\mathrm{w}$ których nie brak serdecznego humoru, na przykład w rozmowie lekarza z pacjentem: „Ta pal więcy, może cie zadusi, coś do mnie przyszed zarazu, idź do (...) Tobin Brothers oni daju zniżki na pogrzeb dla durnych" (Chciuk 1969, 8). Maria Danilewicz-Zielińska pisała:

Nostalgia, ciągoty wspominkarskie i troska o przekazanie odrębności regionalnych, obejmujące w pierwszym rzędzie ziemie kresowe, dyktują potrzebę niejako inwentaryzacji obyczaju i języka - takich, jak zachowały się w pamięci (Danilewicz-Zielińska 1978, 15).

W rozmowie drukowanej na łamach jednego z polonijnych tygodników autor mówił: „Staram się pisać i wiem, że czytelnik lubi przede wszystkim dobrą "story”, a w tym nieco humoru i wzruszenia” (Kowalewski 1970, 4). Emigrant-Chciuk pragnie oswoić Australię, wykorzystując do tego bałak - język swojego dzieciństwa. Ten dopełniający egzystencję pisarza element w rzeczywistości staje się fundamentem jego nowej tożsamości, zaś gwara lwowska jest również sposobem na połączenie rozproszonych w różnych miejscach jej użytkowników.

Kazimierz Wierzyński w wierszu Księżyc pisał:

Za czem ja krążę?

Za księżycem.

Czem on mnie wabi?

Drohobyczem

(Chciuk 2002z, 5)

Jak wynika z zaprezentowanych przykładów, to pograniczne miasto „wabiło” nie tylko jego dawnych mieszkańców, lecz i obcokrajowców, którzy pragnęli skonfrontować wyobrażenie schulzowskiej prowincji z rzeczywistością. Jedno jest pewne: w większości przypadków głównym powodem zainteresowania Drohobyczem była próba uchwycenia jego fenomenu pograniczności i wieloetniczności. Wiadomo, że przedstawiciele każdej wspólnoty narodowościowej tworzyli swój narodowościowy mit tego miasta, jednak ich narracje zazębiały się, ulegały swoistym fluktuacjom. I właśnie na tym polega unikalność i niepowtarzalność dziejowa Drohobycza, nawet jeśli określano go „miastem cebularzy”, zagłębiem soli lub ropy naftowej, a nawet wylęgarnią biedoty. 
Ewa Wiegandt w pracy poświęconej pograniczu kulturowemu powiada: „Ontologiczną zasadą świata jest pograniczność, człowiek pograniczny to kulturowy mieszaniec, normę moralną stanowi tolerancja dla inności" (Wiegandt 2012, 64), co oznacza, że pograniczność to autonomiczna cecha każdego człowieka, którą nosi on w sobie przez całe życie. Uniwersalny aspekt tej dyspozycji uwzględnił także w swoich rozważaniach Tadeusz Bujnicki, według którego pograniczność można interpretować jako „przekraczanie granic" (Bujnicki 2011, 210), co również zyskuje - przynajmniej w teorii - optymistyczny wydźwięk. W tym kontekście słowa Andrzeja Chciuka: „każdy ma swój Drohobycz, każdy ma swoją Atlantydę, swoją szerszą ojczyznę-swojszczyznę" (Chciuk 2002z, 59), wydają się dzisiaj, jak nigdy dotąd, aktualne.

\section{Bibliografia:}

Bagłajewski Arkadiusz, 2014, Andrzej Chciuk - pisarz (z) Drohobycza, „Ruch Literacki", z.1, s. 83-95.

Bujnicki Tadeusz, 2011, Refleksje o literaturze kresowej i pograniczu, w: Gawliński S., Siewior D. (red.), Dwie dekady nowej (?) literatury 19892009, Kraków, s. 201-211.

Bolecki Włodzimierz, Jarzębski Jerzy, Rosiek Stanisław (red), 2003, Słownik schulzowski, Gdańsk.

Cataluccio Francesco M. 2012, Jadę zobaczyć, czy tam jest lepiej, Kraków.

Chciuk Andrzej, 2002a, Atlantyda. Opowieść o Wielkim Księstwie Bałaku, Warszawa.

Chciuk Andrzej, 1969, Lwowskie naciaganie, „Tygodnik Polski”, nr 16, s. 8.

Chciuk Andrzej, 1973, Refleksje w czasie choroby, „Tygodnik Polski”, nr 33, s. 6.

Chciuk Andrzej, 1972, Wizyta w Izraelu, Paryż.

Chciuk Andrzej, 2002z, Ziemia księżycowa. Druga opowieść o Wielkim Księstwie Bałaku, Warszawa.

Czaplejewicz Eugeniusz, 1987, Poetyka literatury emigracyjnej, „Poezja”, nr 4-5, s. 74.

Danilewicz-Zielińska Maria, 1978, Odchylenie od mitu Anteusza, „Pamiętnik Literacki", t. II, s. 15.

Dąbrowski Mieczysław, 2001, Swój/Obcy/Inny, Warszawa.

Delaperrière Maria, 2013, Miejsca pamięci czy pamięć miejsc?, „Ruch Literacki", z 1, s. 49-60.

Döblin Alfred, 2000, Podróż po Polsce, Kraków.

Kasperski Edward, 2007, Dyskurs kresowy. Kryteria, własności, funkcje, w: Trybuś K., Kałążny J., Okulicz-Kozaryn R. (red.), Kresy - dekonstrukcja, Poznań, s. 89-106.

Kowalewski Jan, 1970, Rozmowa z Andrzejem Chciukiem, „Tydzień Polski”, nr 9 , s. 4. 
Olszewska Katarzyna, 2012, Problem antysemityzmu. Z zagadnień współczesnej literatury polskiej, „Podteksty”, nr 1-2.

Próchnicki Włodzimierz 2012, Pogranicza bez granic, w: Fazan J., Zajas K. (red.), Na pograniczach literatury, Kraków, s. 35-51.

Schulz Bruno, 1997, Opowiadania, Warszawa.

Sowa Jan, 2011, Fantomowe ciało króla, Kraków.

Wasilewska-Lipke Zuzanna, 2005, Drohobycka Atlantyda Andrzeja Chciuka, w: Dąbrowski M., Meniok W. (red.), Literatura emigracyjna 1939-1989, Warszawa, s. 105-120.

Weinper Katarzyna, 2009, Przestrzeń Drohobycza - miasta Andrzeja Chciuka, „Wschodni Rocznik Humanistyczny”, t. VI, s. 335-344.

Wiegandt Ewa, 2012, „Pogranicze” jako kategoria interpretacyjna literatury małych ojczyzn, w: Fazan J., Zajas K. (red.), Na pograniczach literatury, Kraków, s. 51-66.

Wierzyński Kazimierz, 1991, Wybór poezji, Wrocław.

Zajas Krzysztof, 2011, Kresy skreślone, czyli o polskiej wielokulturowości, w: Gawliński S., Siewior D. (red.), Dwie dekady nowej (?) literatury 19892009, Kraków, s. 110-121.

Żongołłowicz Bogumiła, 1999, Andrzej Chciuk. Pisarz z antypodów, Kraków.

\section{O Autorze:}

Artur Cembik - absolwent polonistyki Uniwersytetu Warszawskiego, wiedzy o teatrze, filmie i telewizji na Uniwersytecie Gdańskim, doktorantliteraturoznawstwa na Wydziale Filologicznym Uniwersytetu Szczecińskiego. Od ponad 30 lat nauczyciel języka polskiego w Zespole Szkół w Kołbaczu. Autor publikacji dotyczących Andrzeja Chciuka, Brunona Schulza, Mirona Białoszewskiego oraz artykułów w prasie pedagogicznej. Obecnie przygotowuje rozprawę doktorską na temat twórczości Andrzeja Chciuka. 